\title{
PERLINDUNGAN PEMILIK MEREK DAGANG EIK YANG DIGUNAKAN DI INDONESIA MELALUI PERJANJIAN DISTRIBUTOR (ANALISIS PUTUSAN NOMOR 1300 K/Pdt.SUs_HKI/2017)
}

\begin{abstract}
Simona Bustani
(Dosen Fakultas Hukum Universitas Tarumanagara. Meraih Sarjana Hukum pada Fakultas Hukum Universitas Trisakti, Magister Hukum pada Fakultas Hukum Universitas Tarumanagara, Doktor (Dr.) pada Fakultas Hukum Universitas Trisakti)

(E-mail: Simona.funny@gmail.com)

\section{Theodorus Felix Wangsa}

(Mahasiswa Program S1 Fakultas Hukum Universitas Tarumanagara)

Received: 20 Agustus 2019; Accepted: 03 September 2019; Published: 29 Oktober 2019

Abstract

It is still a debate about the controversy of brand protection systems in Indonesia regarding systems first to file. The distributor agreement was also seen to be a gap for principals who did not understand the system first to file. What protection is given to brand owners? Problem research uses normative research with an approach to law and cases. The data used is secondary data. Protection for brand owners who do not register their brands, but sell in Indonesia through a distributor agreement, contained in Article 78 of the brand law. But the weakness of the brand owner must prove itself in the trial of ownership of the brand, so that the owners of foreign brands should register their brands before signing a distribution agreement as a guarantee of the protection of their rights.
\end{abstract}

Keywords: agreement, distributor, protection, brand

\section{PENDAhUluan}

\section{A. Latar Belakang}

Semakin majunya perkembangan teknologi dan komunikasi dalam dunia internasional menunjang berkembanganya perdagangan internasional. hal ini menunjang pemikiran dan pengetahuan seseorang menjadi suatu hal yang penting karena hal tersebut dapat menghasilkan nilai jual seperti halnya buku, obat-obatan, elektronik, karya tulis, karya lukis, dan produkproduk berteknologi yang menjadi sangat berharga karena tidak terlepas dari adanya serangkatian penemuan, 
pembaharuan, dan juga pengujian. Para penemu tersebut pun menerima hak atas barang-barang penemuan dan ciptaan mereka yang mencegah orang lain menggunakan hasil ciptaan dan penemuan mereka. Hak inilah yang kemudian disebut sebagai Hak atas kekayaan Intelektual (selanjutnya disebut HKI).

Semua pihak sudah menyadari pentingnya perlindungan terhadap HKI sehingga permasalahan perlindungan HKI tidak lagi menjadi urusan satu negara melainkan urusan dari masyarakat internasional juga. Pada umumnya HKI dibuat dan digunakan untuk melindungi gagasan atau ide dari penggunaan dan peniruan oleh pihak-pihak tidak bertanggung jawab dengan itikad buruk untuk mencari keuntungan dari ide-ide yang dibuat dan ditemukan oleh sang

penemu.

Sayangnya,Sosialisasi tentang perli ndungan hak kekayaan intelektual yang penting dengan tujuan perlindungan karya ciptaan seseorang masih sangat kurang pada konkretnya dikarenakan masyarakat di Indonesia cenderung bersifat komunal, atau dengan kata lain masih banyak masyarakat Indonesia berpendapat peniruan model dari ciptaannya tidak merugikan dirinya, atau bahkan mereka beranggapan suatu kebanggaan karyanya digunakan pihak lain, yang sebenarnya hal tersebut memiliki nilai jual.

Semua pihak yang merupakan pencipta atau penemu suatu barang atau teknologi diberikan hak ekslusif untuk memperbanyak, membuat, dan menjual serta mengedarkan hasil temuan dan ciptaannya. HKI dengan perlindungan penerapan ide dan informasi memiliki nilai komersil yang merupakan nilai jualnya.

Jadi, HKI pada umumnya berhubungan dengan penerapan ide dan informasi yang memiliki nilai komersial. HKI adalah kekayaan pribadi yang dapat dimiliki dan 
diperlakukan sama dengan bentikbentuk kekayaan lainnya. ${ }^{1)}$

Merek merupakan bagian dari HKI yang memiliki nilai komersil dan arti penting dalam dunia industry karya. Pada era globalisasi ini, perkembangan dan peningkatan yang terjadi baik di bidang komunikasi dan informasi membuat banyak orang berusaha menciptakan suatu karya dan produk yang memiliki nilai komersil tersebut untuk pemenuhan kebutuhan pokok, yang membuat mereka berlomba-lomba membuat suatu karya atau produk yang sejenis untuk mendapatkan keuntungan dari nilai jual tersebut, yang tentunya dapat menarik perhatian masyarakat untuk menggunakan atau menikmati suatu barang, produk atau karya tertentu.

Pengertian dari karya ataupun produk sejenis disini adalah hal-hal yang mempunyai kesamaan seperti

\footnotetext{
${ }^{1)}$ Prof. Tim Lindsey, B.A., LL.., BLitt, Ph.D, Hak
} Kekayaan Intelektual:Suatu Pengantar, 2006. 3 sifat, bentuk, maupun penggunaannya, misalnya air dengan soda, sirup dan benda cair lainnya, karya berbentuk lukisan yang dibedakan dari karakteristik lain, musik, logo, dan semacamnya yang memiliki karakteristik sama namun memiliki unsur pembeda masing-masing. Dalam penciptaan dan penemuan barang barang serupa banyak digunakan merekmerek dengan nama-nama dan logo yang terlihat serupa atau mirip dengan tujuan orang akan terkecoh denga asal dari barang tersebut, seperti kualitas dan pembuatnya, yang dapat dikatakan disinilah itikad tidak baik muncul untuk mendapatkan keuntungan dari ide dan gagasan orang lain yang dimana HKI memberi perlindungan hak kepada penemu dan pencipta tersebut.

Perkembangan hukum merupakan suatu perkembangan nasional pula, seperti halnya hukum yang lain, hukum mengenai HKI pun terus berkembang mengikuti 


\section{ERAA HUKUNÁ

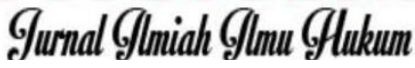 \\ Volume 17, No. 2, Oktober 2019}

Simona Bustani \& Theodorus Felix Wangsa Perlindungan Pemilik Merek Dagang ... perkembangan yang terjadi di masyarakat yang terus berubah dengan cepat karena pengaruh globalisasi. Undang-undang yang mengatur mengenai HKI yang berhubungan kasus yang penulis angkat adalah Undang-Undang nomor 20 tahun 2016 tentang Merek dan Indikasi Geografis.

Di Indonesia kerap kali terjadi sengketa merek antara lain mengenai klaim atas merek, pendaftaran beriktikad tidak baik, persamaan merek dan hak cipta pada keseluruhan atau persamaan pada pokoknya, peniruan merek terkenal, dan lain-lain, baik merekmerek dan karya dalam negeri maupun lintas negara, hal ini mengakibatkan timbulnya kesadaran masyarakat internasional mengenai cara melindungi kepentingan-kepentingan para penemu dan pencipta yang membuat suatu karya atau produk yang tidak diketahui oleh negara lain, dan ternyata sudah dibuat di negara lain, karena hal ini lah timbul kesadaran akhirnya diatur lah perlindungan untuk subjek hukum baik perorangan maupun badan usaha asing yang akan mendaftarkan karya dan produknya ke negara lain, hal inilah yang berkaitan dengan hak teritorial dari HKI itu sendiri.

Pengaturan internasional HKI tidak dapat dipisahkan dari sistem HKI Indonesia, karena merupakan sumber yang penting bagi sumber hukum HKI Indonesia, Saat ini Indonesia menjadi peserta yang aktif dalam pengembangan HKI sebagai negara peserta dalam Organisasi Perdagangan Dunia (WTO) dan Organisasi HKI Dunia (WIPO). ${ }^{2)}$

Munculnya merek-merek dan karya yang informasinya mudah menyebar karena era globalisasi, tidak luput dari berbagai persoalan yang terjadi. Seperti misalnya kasus antara EIK Engineering SDN. BHD sebagai penggugat melawan PT

\footnotetext{
2) Ibid.,24
} 
Engineering

Indonesia

Karya sebagai tergugat, dalam

kasus ini PT Engineering Indonesia

Karya yang merupakan distributor dair EIK Engineering SDN. SBH mendaftarkan merek EIKA ke Direktorat HKI untuk mendapatkan perlindungan pada 2012, sedangkan perjanjian distribusi dengan merek EIK dari Malaysia telah berakhir dengan pemberitahuan yang sudah jelas oleh penggugat pada tanggal 15 September 2015 dengan surat pengakhiran perjanjian distribusi ( Termination of Distribution Agreement ). Kemudian Penggugat menunjuk pihak lain sebagai distributornya yaitu PT Trikarya Abadi Prima. Ternyata sekitar bulan Februari terjadi penggeledahan dan penyitaan terhadap PT Trikarya Abadi Prima berdasarkan adanya pelanggaran hak atas merek milik tergugat. Maka dari kasus tersebut, penulis tertarik untuk membahas kasus tersebut untuk melihat apakah perjanjian distributor dapat dijadikan celah pelanggaran pada sistem first to file yang dianut
Indonesia dan menuliskannya dalam skipsi yang berjudul "Perlindungan Pemilik Merek Dagang EIK Yang Digunakan Di Indonesia Melalui Perjanjian Distributor (Analisis Putusan Nomor 1300

K/Pdt.Sus_Hki/2017)".

\section{A. Perumusan Masalah}

$$
\begin{aligned}
& \text { Berdasarkan uraian latar } \\
& \text { belakang di atas, maka } \\
& \text { permasalahan yang hendak } \\
& \text { dianalisis oleh penulis adalah: } \\
& \text { Bagaimana perlindungan pemilik } \\
& \text { merek dagang EIK yang belum } \\
& \text { terdaftar dan digunakan di } \\
& \text { Indonesia melalui perjanjian } \\
& \text { distributor berdasarkan putusan } \\
& \text { nomor } 1300 \text { K/Pdt.Sus_Hki/2017 }
\end{aligned}
$$

\section{B. Metode Penelitian}

Metode penelitian hukum merupakan suatu proses untuk menemukan aturan hukum, prinsipprinsip hukum, maupun doktrindoktrin hukum guna menjawab isu hukum yang akan dihadapi. Metode merupakan suatu unsur mutlak yang harus ada dalam suatu penelitian 
yang berfungsi untuk mengembangkan

pengetahuan. ${ }^{3)}$

Metode penelitian yang penulis gunakan dalam penelitian ini adalah metode penelitian hukum Normatif. Metode penelitian hukum jenis ini juga biasa disebut sebagai penelitian hukum doktriner atau penelitian perpustakaan. Dinamakan penelitian hukum doktriner dikarenakan penelitian ini hanya ditujukan pada peraturanperaturan tertulis sehingga penelitian ini sangat erat hubungannya pada perpustakaan karena akan membutuhkan datadata yang bersifat sekunder pada perpustakaan. Dalam penelitian hukum Normatif, hukum yang tertulis dikaji dari asas-asas hukum merek.

Adapun metode pengumpulan data yang dipergunakan dalam penelitian ini adalah studi

3 ) Soerjono Soekanto, Pengantar Penelitian Hukum, (Jakarta: UI Press, 1981), 7. kepustakaan (Library Research).

Sumber data diperoleh dari:

a. Bahan hukum primer, yaitu bahan-bahan hukum yang mengikat, dan terdiri dari:

1) Undang-undang mengenai merek, yaitu undang-undang nomor 20 tahun 2016

2) Undang-undang dan keputusan Menteri mengenai distributor dan keagenan.

3) Kitab Undang-Undang Hukum Perdata, yaitu mengenai perjanjian.

4) Putusan hakim

b. Bahan hukum sekunder, yaitu bahan yang tidak mengikat, tetapi memberikan penjelasan mengenai bahan hukum primer, seperti jurnal hukum di bidang merek dan distributor

c. Bahan hukum tersier, yaitu ensiklopedia atau kamus. Kamus yang digunakan adalah Kamus Besar Bahasa Indonesia 
Dalam pendekatan penelitian ini, penulis akan menggunakan pendekatan undang-undang dan kasus. Pendekatan undang-undang adalah pendekatan yang dilakukan dengan menelaah semua undangundang dan regulasi yang bersangkut paut dengan isu hukum yang sedang ditangani. ${ }^{4}$ ) Dalam pendekatan undang-undang ini adalah undang-undang merek, dan peraturan Menteri tentang pedoman pembangunan dan pengelolaan sarana perdagangan. Dan untuk pendekatan kasus, kasus yang ditelaah adalah kasus dalam putusan Mahkamah Agung Nomor 1300 K/Pdt.Sus_Hki/2017 yaitu antara Eik Engineering Sdn. Bhd Vs PT Engineering Indonesia Karya.

Teknik pengumpulan data yang digunakan dalam penulisan ini adalah dengan studi dokumen dan studi lapangan. terhadap bahanbahan hukum, baik bahan hukum primer, dan bahan hukum sekunder.
Penelusuran bahan-bahan hukum tersebut dapat dilakukan dengan membaca, melihat, mendengarkan, maupun melalui media internet. ${ }^{5 \text { ) }}$

Setelah data dan bahan hukum dikumpulkan, tahap selanjutnya adalah melakukan pengolahan data, yaitu mengelola data sedemikian rupa sehingga data dan bahan hukum tersebut tersusun secara runtut dan sistematis. ${ }^{6}$ )

\section{PEMBAHASAN}

\section{A. Perlindungan Pemilik Merek Dagang EIK yang Belum Terdaftar dan Digunakan Di Indonesia Melalui Perjanjian Distributor}

Untuk mengetahui apakah melalui perjanjian distributor dapat dijadikan celah pelanggaran merek pada sistem first to file di Indonesia, maka adapun analisis perlindungan terhadap contoh kasus pelanggaran merek EIK sebagai berikut.

4 'Mukti Fajar ND dan Yulianto Achmad, Dualisme Penelitian Hukum Normatif dan Empiris (Yogyakarta: Pustaka Belajar, 2015), ${ }^{5)}$ Ibid, 160. 43.

\footnotetext{
${ }^{6)}$ Peter Mahmud Marzuki, Op. Cit., 180.
} 
Perusahaan Penggugat, Eik penggunaan atas Merek "EIK" milik Engineering Sdn. Bhd., adalah Penggugat pada acara sidang sebuah perusahaan yang didirikan pembuktian; berikut adalah contoh pada tahun 2006 dan bergerak pada bidang usaha produksi mesin penggali amfibi (amphibious penggunaan dari merek "EIK" milik Penggugat yang diambil dari situs resmi Penggugat

excavator) beserta produksi alat-alat pelengkap untuk berbagai model mesin pengeruk amfibi; Dengan pusat pabrik berada di Negara Malaysia, Penggugat menggunakan lahan seluas 300,000 kaki untuk proses produksi dan juga didukung oleh lebih dari 300 karyawan tetap. Penggugat adalah produsen mesin pengeruk terbesar di wilayah Asia Tenggara dan telah memperoleh berbagai penghargaan dan pengakuan atas kualitas produksi mesin pengeruk yang diproduksinya mesin pengeruk yang diproduksi oleh Penggugat diperdagangkan dengan menggunakan merek dagang "EIK". Contoh-contoh penggunaan Merek "EIK" milik Penggugat di dalam kegiatan perdagangan dapat dicermati dari berbagai informasi yang tersedia di Internet. Penggugat Pada awal Tahun 2012, Penggugat bermaksud untuk mengembangkan bisnisnya di Indonesia yaitu dengan cara menunjukan distributor resmi untuk mendistribusikan produk-produk excavator milik Penggugat di Indonesia; Setelah cukup lama menjajaki pangsa pasar di Indonesia, maka akhirnya berdirilah PT Engineering Karya Indonesia (Tergugat di dalam perkara a quo) sebagai pihak lokal di Indonesia yang akan mendistribusikan produkproduk milik Penggugat di Indonesia. Sedari awal pendiriannya, Perusahan Tergugat yaitu PT Engineering Karya Indonesia memang berdiri untuk tujuan spesifik pendistribusian produk-produk Penggugat di Indonesia. 
Hubungan distribusi antara Penggugat dan Tergugat tertuang di dalam sebuah Distributor Agreement (Perjanjian Distribusi) yang ditandantangani oleh Penggugat dan Tergugat dan berlaku selama 3 (tiga) sejak ditandatanganinya Perjanjian Distribusi. Perjanjian Distribusi mulai berlaku sejak tanggal 15 Oktober 2012 sampai dengan tanggal 15 Oktober 2015.

\section{Di dalam Pasal 3 dari} Perjanjian Distributor tersebut telah ditegaskan masa berlakunya perjanjian adalah selama 3 tahun.

Selama masa kontrak, hubungan distributor antara Penggugat dan Tergugat berdasarkan Distributor Agreement dapat berjalan lancar. Hal ini terbukti dari fakta bahwa Penggugat telah berkali-kali mengirimkan produkproduk dengan merek "EIK" ke Tergugat untuk diedarkan di Indonesia.

\section{Pada tanggal 15 September 2015, Penggugat selanjutnya mengirimkan Surat Pengakhiran}

Perjanjian Distribusi (Termination of Distribution Agreement) kepada Tergugat dengan isi secara umum memberitahukan kepada Tergugat bahwa Penggugat telah memutuskan untuk tidak memperpanjang masa kontrak berdasarkan Perjanjian Distribusi dan pemutusan tersebut akan berlaku efektif sejak tanggal 15 Oktober 2015; Adapun alasan Penggugat mengakhiri Perjanjian Distributor dengan Tergugat adalah karena ternyata Tergugat tidak dapat memenuhi target penjualan sebagaimana telah dijanjikan pada awal kontrak; Pada tanggal 15 Oktober 2015, Penggugat mengirimkan surat lagi kepada Tergugat yang isinya merupakan penegasan klausula pengakhiran perjanjian di dalam P.erjanjian Diatribusi babwa hubungan distributor antara Penggugat dan Tergugat telah berakhir;

Setelah berakhirnya Perjanjian Distribusi antara Penggugat dengan Tergugat, Penggugat kemudian menunjuk perusahaan lain di 
Indonesia untuk menjadi "EIK" yang terdaftar atas nama distributornya, yaitu sebuah Tergugat di kantor Turut Tergugat.

perusahaan yang berkedudukan di

Jakarta dan bernama PT Trikarya Abadi Prima; Bahwa selama masa Perjanjian Distribusi antara Penggugat dengan PT Trikarya Abadi Prima, Penggugat telah berkali-kali mengirimkan produkdengan merek "EIK" untuk diedarkan oleh PT Trikarya Abadi Prima diIndonesia.

Bahwa ternyata, sekitar bulan Februari 2016, Direktorat Tindak PidanaEkonomi Khusus dari Markas Besar Polisi Republik Indonesia melakukan penggeledahan dan penyitaan terhadap PT Trikarya Abadi Prima berdasarkan dugaan adanya pelanggaran hak atas merek "EIK"milik Tergugat; Berdasarkan keterangan yang diterima oleh PT Trikarya Abadi Prima dari petugas Mabes Poiri, ternyata memang benar bahwa Tergugat telah mengajukan Laporan Tindak Pidana terhadap PT Trikarya Abadi Prima berdasarkan dugaan pelanggaran hak atas merek

Berdasarkan hasil penelusuran yang dilakukan oleh Penggugat di kantor Turut Tergugat, ternyata memang benar telah terdaftar merek "EIK" milik Tergugat

Atas nama Tergugat dengan semua tanggal pendaftaran 24 Januari 2015, untuk jenis barang sebagai berikut: Bagian-bagian dan perlengkapan dari mesin penggali (parts and fittings of excavator), yaitu: lengan atas mesin penggali (excavator boom); batang pemberi gaya penggalian (excavator stick); alat penggerak amfibi (amphibious undercarriage), bahwa ketiga pendaftaran merek yang mengandung unsur kata "EIK" di atas selanjutnya di dalam Gugatan inidisebut sebagai Merek "EIK" milik Tergugat.

Penggugat terkejut ketika mengetahui fakta bahwa Tergugat ternyata telah mendaftarkan merek "EIK" di Indonesia tanpa adanya persetujuan dari Penggugat selaku 
pemilik yang sah atas merek "EIK". Penggugat juga sangat menyesalkan manipulasi hukum yang dilakukan oleh Tergugat dengan mengajukan laporan pidana kepada pihak kepolisian terhadap distributor baru Penggugat di Indonesia, yaitu PT Trikarya Abadi Prima;

Tergugat telah mendaftarkan merek "EIK" tersebut ketika telah terjadi kesepatakan antara Penggugat dan Tergugat untuk menjalin hubungan bisnis untuk mendistribusikan produkproduk milik Penggugat yang menggunakan merek "EIK" untuk pangsa pasar di Indonesia

\section{Tergugat}

ternyata mempergunakan pendaftaran merek "EIK" yang telah didaftar menjadi dasar laporan polisi, atas dasar latar belakang ini, penggugat mengajukan gugatan atas persamaan pada pokoknya pada tergugat.

Perlindungan merek dilakukan oleh negara dan negara sebagai penanggung jawab dan pelindung dalam pelaksanaaanya, di Indonesia sebagai suatu negara sudah berperan aktif dalam perlindungan hak kekayaan intelektual yang khusus dibahas disini adalah mengenai merek. Hal ini dapat dilihat dengan pemberlakuan undang-undang merek sejak tahun 1961 (UU no.21 tahun 1961), serta keikut sertaan Indonesia sebagai peserta dalam berbagai konvensi internasional yang mengakibatkan perubahan-perubahan dalam hukum merek yang akhirnya ditetapkanlah Undang-Undang no.20 tahun 2016 sebagai undang-undang merek yang berlaku sampai sekarang.

Perbedaan dari undang-undang lama dan yang semakin memberi perlindungan yang jelas diantaranya adalah perluasan tipe merek, perubahan alur pendaftaran merek, jangka waktu proses pendaftaran merek sampai diberikan sertifikat yang semakin cepat, perpanjangan pendaftaran merek, pengaturan pendaftaran merek internasional, pengaturan indikasi geografis, dan pengaturan ketentuan pidana. 


\section{ERAA Hüroina

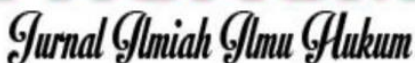 \\ Volume 17, No. 2, Oktober 2019}

Simona Bustani \& Theodorus Felix Wangsa Perlindungan Pemilik Merek Dagang ...
Dalam wawancara dengan Dr. Gunawan Widjaja S.H., M.H., M.M., beliau mengatakan dalam hal pemberian perlindungan atas merek, Indonesia menggunakan sistem first to file yang artinya dalam pemberian perlindungannya, perlu didaftarkan dulu di Indonesia, namun sistem first to file mengandung banyak kontroversi pada prakteknya, yaitu dimana Indonesia masih terlalu sering mengutamakan first to use yang bertentangan dengan asas first to file yang dianutnya. Biasanya digunakan first to use lalu baru menggunakan first to file jika tidak dapat membuktikannya.

Pada kasus ini, prinsipal atau disini sebagai penggugat tidak mendaftarkan mereknya di Indonesia untuk mendapatkan perlindungan, ia melakukan perjanjian distribusi tanpa adanya lisensi merek dengan distributornya atau disini sebagai penggugat. Menurut Dr. Gunawan Widjaja S.H.,M.H.,M.M. dan Dr. Suyud Margono, S.H., MHum., FCIArb. dalam hal ini, hal ini seharusnya dilakukan oleh prinsipal sebelum melakukan perjanjian distribusi di Indonesia, namun bukan merupakan hal yang dapat disalahkan, hal ini adalah hal yang hanya sebaiknya dilakukan sebelum melakukan perjanjian distribusi, dengan tujuan agar tidak terjadi penyalahgunaan wewenang oleh distributornya. Pada umumnya memang dalam perjanjian merek telah diatur mengenai merek dan penggunaannya, namun sebaiknya pendaftaran dilakukan melihat sistem perlindungan merek di Indonesia (tujuan distribusi) adalah menganut sistem first to file.

Undang-undang merek namun tetap mengatur perlindungan untuk pemilik merek, melihat bagaimana keadaan pada praktiknya sering terjadi penyalahgunaan wewenang, hal ini dilakukan dengan pemberlakuan pasal 76 pada undangundang nomor 20 tahun 2016 dan dulu diatur pada undang-undang nomor 15 tahun 2001 yaitu:

Pasal 76 mengenai pembatalan, menyatakan: 
1. Gugatan pembatalan Merek terdaftar dapat diajukan oleh pihak yang berkepentingan berdasarkan alasan sebagaimana dimaksud dalam Pasal 20 dan/atau Pasal 21.

2. Pemilik Merek yang tidak terdaftar dapat mengajukan gugatan sebagaimana dimaksud pada ayat (1) setelah mengajukan

Permohonan kepada

Menteri.

3. Gugatan pembatalan diajukan kepada Pengadilan Niaga terhadap pemilik Merek terdaftar.

Dalam hal ini, prinsipal tidak mendaftarkan mereknya, maka perlindungan yang dapat menjamin haknya diatur pada pasal 76 (b) mengenai pembatalan, dalam melakukan pembatalan, pihak harus berkepentingan, berbeda dengan penghapusan yang dapat dilakukan oleh pihak mana pun, dalam hal ini pihak prinsipal atau penggugat belum memiliki kepentingan untuk menggugat merek tergugat, maka dari itu dikatakan pada pasal 76 (b):

"Pemilik Merek yang tidak terdaftar dapat mengajukan gugatan sebagaimana dimaksud pada ayat (1) setelah mengajukan Permohonan kepada Menteri."

Untuk mendapat kepentingan untuk menggugat, prinsipal mengajukan gugatan kepada Menteri untuk melakukan pendaftaran terlebih dahulu untuk kepentingan melakukan pembatalan kepada tergugat, yang nantinya penggugat sendiri yang memiliki kewajiban membuktikan sendiri dari kepemilikannya atas merek tersebut.

Dalam kasus ini, menurut hasil wawancara dengan Dr. Suyud Margono, S.H., MHum., FCIArb kasus ini selanjutnya lebih berfokus pada inti dari kasus pembatalannya, yang mengacu pada persamaan pada pokoknya, dan itikad tidak baik dari tergugat yang dibuktikan dari latar belakang kasus itu sendiri. 
1. Persamaan Pada Pokoknya

Penjelasan Pasal 6 ayat (1)

(a) dari Undang Undang Merek menyebutkan bahwa yang dimaksud dengan persamaan pada pokoknya adalah:

“...Kemiripan yang disebabkan oleh adanya unsur-unsur yang menonjol antara Merek yang satu dan Merek yang lain, yang dapat menimbulkan kesan adanya persamaan balk mengenai bentuk, cara penempatan, cara penulisan atau kombinasi antara unsurunsur atau persamaan bunyi ucapan yang terdapat dalam merek-merek tersebut;

Berdasarkan penjelasan Pasal 6 ayat (1) (a) Undang Undang Merek tersebut di atas, dapat dipahami bahwa "nsurunsur yang menonjol" terhadap suatu merek menjadi faktor utama dalam menentukan suatu persamaan antara suatu merek dengan merek lainnya. setelah unsur-unsur utama yang menonjol dapat ditentukan, maka yang perlu diperhatikan kemudian adalah cara menganalisa persamaan antara merek yang bersangkutan dengan merek pembandingnya. Sehubungan analisa persamaan antara merek bersangkutan, Yurisprudensi Mahkamah Agung Rl, diantaranya di bawah Nomor 279 PK/Pdt/1992 tanggal 6 Januari 1998, menyatakan bahwa suatu merek mempunyai persamaan pada pokoknya maupun secara keseluruhan jika:

1. Persamaan bentuk (similarity of form);

2. Persamaan komposisi (similarity of composition);

3. Persamaan kombinasi (similarity of combination);

4. Persamaan unsur elemen (similarity of elements); 
Volume 17, No. 2, Oktober 2019

5. Persamaan bunyi

(sound similarity);

6. Persamaan ucapan (phonetic similarity) atau;

7. Persamaan penampilan (similarity in appearance);

Dalam kasus ini yang menjadi permasalahan persamaan pada pokoknya milik penggugat dan tergugat adalah Persamaan unsur utama yang membentuk merek-merek tersebut. Bahwa, adanya unsur kata "EIK" dalam huruf kapital pada desain kotak yang dipadukan dengan garis strip dimana penempatan kata EIK tersebut adalah di atas garis strip dalam kombinasi warna merah hitam dan putih pada merek "EIK" Tergugat tersebut, nyata dan jelas memiliki persamaan pada pokoknya dengan dengan Merek "EIK" milik Penggugat, karena merek-merek tersebut

sama-sama menggunakan penggunaan kombinasi huruf kapital "E", "I" dan "K" yang membentuk kata "EIK", penggunaan unsur kotak, penggunaan garis strip, penempatan kata "EIK" di atas garis strip, dan penggunaan tiga kombinasi warna yaitu hitam, putih dan merah, Persamaan utama tersebut di atas jelas menunjukkan adanya persamaan dalam bentuk, komposisi, kombinasi dan elemen.Kemudian persamaan tampilan yang membentuk merek-merek tersebut juga memiliki persamaan pada pokoknya. Dengan mengingat adanya persamaan pada bentuk, komposisi, kombinasi dan elemen, maka terlihat jelas bahwa dalam perspektif persamaan pada tampilan, maka merek "EIK" Tergugat memiliki persamaan pada pokoknya dengan merek "EIK" milik Penggugat, ada juga persamaan bunyi dan ucapan 
antara merek-merek tersebut sama pada pokoknya.

Selain daripada persamaan pada unsur-unsur pembentuk merek di atas, mengingat bahwa merek "EIK" milik Tergugat terdapat persamaan kelas barana dan ienis barana. yaitu sama-sama melindungi jenis barang yang sama di Kelas 7; Jenis barang yang terdapat pada merek "EIK" Tergugat memiliki persamaan pada pokoknya dengan jenis barang yang dilindungi pada merek "EIK" milik Penggugat.

\section{Itikad Tidak Baik}

Ketentuan penjelasan Pasal 4 Undang Undang Merek Nomor 15 Tahun 2001, menyatakan bahwa:

"Pemohon yang beritikad baik adalah Pemohon yang mendaftarkan mereknya secara fayak dan jujur tanpa ada niat apapun untuk memboncang, meniru atau menjiplak ketenaran merek pihak lain demi kepentingan usahanya yang berakibat kerugian pada pihak lain itu atau menimbulkan kondisi persaingan curang, mengecoh atau menyesatkan konsumen...";

Fakta bahwa Tergugat telah mendaftarkan merek "EIK" tanpa adanya persetujuan dari Penggugat telah membuktikan bahwa Tergugat adalah pendaftar dengan itikad tidak sesuai dengan ketentuan Pasal 4 Undang Undang Merek di atas.

Menurut hasil wawancara dengan Dr. Suyud Margono, S.H., MHum., FCIArb Tergugat telah mendaftarkan merek "EIK" tersebut ketika telah terjadi kesepakatan antara Penggugat dan Tergugat untuk menjalin hubungan bisnis untuk mendistribusikan produkproduk milik Penggugat yang menggunakan merek 
"EIK" untuk pangsa pasar di Indonesia, hal ini merupakan latar belakang utama penarikan kesimpulan untuk itikad tidak baik.

\section{Tergugat ternyata} mempergunakan pendaftaran merek "EIK" yang telah didaftar dengan itikad tidak baik menjadi dasar iaporan polisi, merupakan suatu bukti sempurna bahwa Tergugat telah memperalat sistem first to file pendaftaran merek di Indonesia.

Tergugat masih tetap mengaku sebagai distributor resmi dari Penggugat di Indonesia. Fakta ini dapat dicermati dari situs resmi milik Tergugat

Selain daripada klaim sebagai distributor resmi di halaman situs www.eika.co.id. ternyata Penggugat juga merekrut karyawannya dengan mengaku sebagai distributor resmi untuk produk dengan merek "EIK" yang diproduksi oleh Penggugat, yang dilakukan pada situs pencari lowongan pekerjaan, yaitu www.jobstreet.co.id

Itikad tidak baik Tergugat juga dapat dicermati dari fakta bahwa kata "ElK" bukanlah kata ataupun penamaan yang berasal dari Bahasa Indonesia sehingga dapat disimpulkan bahwa Merek "ElK" Tergugat pada dasarnya adalah tiruan merek “EIK” milik Penggugat

Faktor itikad tidak baik lainnya yang perlu dicermati adalah tanggal pendaftaran antara kedua merek yang secara nyata membuktikan bahwa Merek "ElK" Penggugat telah terdaftar jauh sebelum Merek "ElK" Tergugat terdaftar di Indonesia

$$
\text { Adapun tanggal }
$$

pendaftaran yang pertama kali untuk merek "ElK" milik 
Penggugat adalah tanggal 6

Februari 2007 di negara

Malaysia; Sementara itu, merek

"EIK" milik Tergugat terdaftar

pada tanggal 24 Januari 2015.

Karena Merek "ElK" milik

Penggugat telah terdaftar

setidak-tidaknya 8 tahun

sebelum pendaftaran merek

"EIK" milik Tergugat, maka

jelas bahwa Tergugat memang

mendaftarkan mereknya karena

terinspirasi dari merek "ElK"

milik Penggugat.

Berdasarkan uraian di atas, itikad tidak baik Tergugat dalam mendaftarkan merek "ElK" terbukti dengan sempurna dari fakta-fakta yaitu sudah sewajarnya tergugat mengetahui bahwa penggugat merupakan pengguna pertama merek tersebut mengingat hubungan hukum antara penggugat dan tergugat dalam perjanjian distributor. Adanya pendaftaran tanpa izin yang dilakukan oleh tergugat. Pendaftaran dilakukan oleh tergugat setelah penunjukan sebagai distributor penggugat di Indonesia untuk menjualkan produk-produk penggugat. Tergugat tidak pernah memberitahukan kepada Penggugat bahwa Tergugat telah mendaftarkan merek "EIK", Merek "EIK" milik Penggugat, telah terdaftar setidak-tidaknya 8 tahun sebelum pendaftaran merek "EIK" milik Tergugat di kantor Turut Tergugat, Tergugat telah menggunakan merek "EIK" tersebut sebagai dasar hukum dalam pengajuan laporan pidana terhadap Trikarya Abadi Prima yang merupakan distributor Penggugat untuk menggantikan Tergugat, Tergugat masih mengaku sebagai distributor resmi atas produk-produk dengan merek "EIK" milik Penggugat dan Tergugat masih membuka lowongan kerja dengan mengaku sebagai distributor resmi atas pfoduk-produk 
dengan merek "EIK" milik Penggugat.

$\begin{array}{rcr}\text { Setiap } & \text { orang } & \text { atau } \\ \text { organisasi } & \text { perusahaan } & \text { yang }\end{array}$
ada, akan sangat peduli akan pentingnya sebuah nama dan simbol yang digunakan dalam menjalankan bisnis dan pemasaran barang dan jasa. Simbol-simbol ini akan membantu untuk menunjukkan asal barang dan/atau jasa, serta perusahaan komersial yang bergerak dalam bidang dan menyediakan barang dan jasa. Dalam pangsa pasar, namanama dan simbol-simbol tersebut dikenali sebagai merek (trademark), nama usaha (business name), dan nama perusahaan (company name). Perbedaan ketiganya kadangkadang membuat bingung, baik bagi pengusaha itu sendiri maupun masyarakat. ${ }^{7)}$

7) Rahmi Jened, Hukum Merek Dalam Era Global \& Integrasi Ekonomi, (Jakarta: Prenadamedia Group, 2015), hal. 3

\section{Pembatalan Merek}

Perlu diketahui secara jelas bahwa mengapa yang dilakukan adalah pembatalan dalam kasus ini

Pasal 76 mengenai pembatalan, menyatakan:

a. Gugatan pernbatalan Merek terdaftar dapat diajukan oleh pihak yang berkepentingan berdasarkan alasan sebagaimana dimaksud dalam Pasal 20 dan/atau Pasal 21.

b. Pemilik Merek yang tidak terdaftar dapat mengajukan gugatan sebagaimana dimaksud pada ayat (1) setelah mengajukan

Permohonan kepada Menteri.

c. Gugatan pembatalan diajukan kepada Pengadilan Niaga terhadap pemilik Merek terdaftar. 
Menurut Dr. Suyud Margono, S.H., MHum., FCIArb , dalam kasus ini yang digunakan adalah pembatalan merek, yang dimana berdasarkan pasal 76 undangundang merek menyatakan pihak yang berkepentingan berdasarkan alasan sebagaiman dimaksud dalam pasal 20 dan/atau pasal 21, dalam kasus ini pengguat merupakan Pemilik merek yang tidak terdaftar, berdasarkan huruf $b$ pasal 76, harus mengajukan permohonan dulu kepada Menteri, kemudian setelah mendapatkan pendaftaran untuk kepentingan menggugat, pihak penggugat menjadi pihak yang berkepentingan. Maka dari itu disebutkan bahwa perlindungan utama untuk kasus ini berada pada pasal 76 Undang-Undang Merek.

II. PENUTUP

\section{A. Kesimpulan}

Perlindungan yang diberikan kepada pemilik merek EIK, yang terjadi karena berakhirnya perjanjian distributor dengan pihak PT. Engineering Indonesia Karya, kemudian terjadi pendaftaran merek EIK oleh tergugat dalam kasus ini sesaat sebelum perjanjian berakhir. Hal ini terjadi karena dalam melakukan perjanjian distributornya, pihak penggugat tidak mendaftarkan mereknya terlebih dahulu di Indonesia dan melakukan suatu lisensi merek dengan distributornya. Hal ini memberi celah kepada tergugat yang merupakan distributornya di Indonesia, pada sistem first to file yang dianut di Indonesia, di mana untuk mendapatkan perlindungan, suatu merek harus didaftarkan ke Direktorat Jenderal HKI.

Namun sebenarnya, ternyata hal ini tidak bisa menyalahkan penggugat karena tidak mendaftarkan mereknya terlebih dahulu dan melakukan lisensi merek, hal ini sebenarnya 
merupakan suatu jaminan untuk tidak terjadi hal semacam ini. Bagaimanapun juga, merupakan fakta bahwa pemilik merek EIK tersebut berasal dari Malaysia sebagai prinsipal terhadap tergugat.

Hal ini sebenarnya sudah diatur dalam perjanjian distributor ini sendiri dan termasuk dalam hal-hal yang diatur supaya tidak memberikan kekuasaan berlebih kepada distributor atau perpanjangan tangan-tangan yang lainnya, maka dari itu dapat dilihat dari mulanya terjadi pelanggan perjanjian yang seharusnya menjadi undang-undang bagi para pihaknya (pacta sun servanda)

Perlindungan merek yang diberikan terhadap pemilik merek EIK di Malaysia sebagai prinsipal dalam kasus ini diatur utamanya pada pasal 76 Undang-Undang merek no.20 tahun 2016 yang sebelumnya diatur pada Undangundang merek no.15 tahun 2001 pada pasal 68. Ini memberikan perlindungan dengan menyatakan
"Pemilik Merek yang tidak terdaftar dapat mengajukan gugatan sebagaimana dimaksud pada ayat (1) setelah mengajukan Permohonan kepada Menteri." Dalam hal ini untuk melakukan suatu pembatalan, pihak penggugat harusnlah menjadi orang yang mempunyai kepentingan untuk menggugat, maka dari itu dengan adanya pasal ini memberi peluang untuk pemilik merek mendaftarkan mereknya dengan tujuan keperluan menggugat untuk pembatalannya, setelah itu pemilik merek mempunyai kewajiban membuktikan kepemilikannya dalam persidangan. Hal ini melindungi pemilik merek dari celah-celah sistem first to file di Indonesia

Dalam kasus ini dengan adanya perlindungan tersebut memberi pengertian bahwa perjanjian distributor tidak dapat dijadikan suatu celah atau jalan untuk pelanggaran merek di 


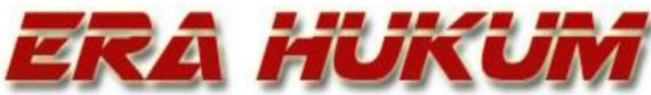

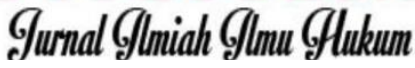 \\ Volume 17, No. 2, Oktober 2019}

Indonesia yang menganut sistem first to file.

\section{B. Saran}

Telah banyak terjadi kasuskasus pelanggaran baik dalam hal itikad tidak baik ataupun persamaan pada pokoknya dalam hal untuk membonceng ketenaran merek pihak lain dan akan sangat merugikan karena dapat membingungkan pasar, sebagai salah satu contohnya adalah kasus yang terjadi karena pendaftaran merek akibat berakhirnya suatu hubungan distributor di Indonesia tanpa adanya perlindungan merek sehingga tidak adanya perlindungan untuk merek tersebut, mengingat Indonesia menganut sistem first to file. Untuk menghindari hal-hal seperti ini, khususnya dalam menjalankan hubungan distributor, sebaiknya lakukan pendaftaran merek terlebih dahulu di Indonesia, barulah menjalankan perjanjian distributor dengan pihak yang ditunjuk, disertai dengan lisensi merek dari prinsipal, sebab suatu
Simona Bustani \& Theodorus Felix Wangsa Perlindungan Pemilik Merek Dagang ...

merek yang sudah terdaftar mendapatkan perlindungan dan direktoran jenderal HKI akan menolak suatu pendaftaran merek dengan nama yang sama, sehingga tidak terjadi hal-hal yang menimbulkan suatu penyalahgunaan dengan itikad tidak baik dan perlu adanya pemahan yang lebih baik mengenai perlindungan merek oleh pemilik merek asing, terutama yang ingin memasarkan produknya di suatu negara.

\section{DAFTAR PUSTAKA}

\section{A. Buku}

Jened, Rahmi, Hukum Merek Dalam Era Global \& Integrasi Ekonomi, Jakarta: Prenadamedia Group, 2015

Djumhana, Muhammad, R. Djubaedillah, Hak Milik Intelektual (Sejarah Teori dan Prakteknya di Indonesia), Bandung: PT.Citra Aditya Bakti, 2003 